\title{
Cross Border Marriages (CBM's) Between Pakistan To Developed Countries: A Socio-Economic Perspective
}

\author{
Shagufta Jahangir \\ \& \\ Asma Manzoor \\ Women Studies \\ University of Karachi
}

\begin{abstract}
According to many researches, the third world youth crave to go to developed countries just merely to get sustainable economic development. To accomplish their wish they use every possible way like cross border marriages (CBM'S) is one of them. The basic and main purpose of CBM'S is financial sustainability neither culture nor religion or others. The findings shows that most Pakistanis leave Pakistan only for economic stability, 10 per cent for better education, 10 per cent for improving living standard, while 16.6 per cent for economic (These all are simply economic reasons to pay court to women on inter-racial grounds) and education reasons while $3.4 \%$ leave for political or criminal issue. Due to these thoughts these people flipside to their native areas with only economic firmness rather social attitudes, moral attitudes behaviors, norms, myths and religion. The study shows that men do CBM'S to get firmness even they have families in their native areas. Second family formation is the easy way to get their desires, i.e. legal cover and residence. After satisfying their needs they come back to their native areas, even they leave behind their offspring because they give priority to their inhabitant families. In this situation foreigner wife or offspring face problems economically, socially and mentally. This article aims to describe that economic reasons are the basic phenomena of CBM'S for the third world countries' people who prefer to go to developed countries and to live without facing legal issues.
\end{abstract}

Keywords: Cross Border Marriages, Moral Attitudes, Native Areas, Flipside, Norms.

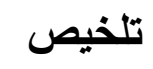

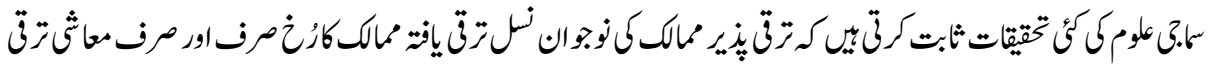

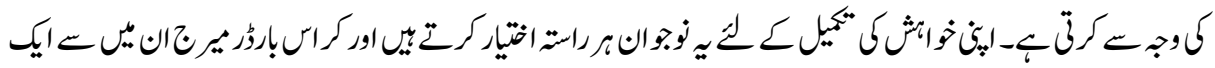

$$
\begin{aligned}
& \text { 46BM's-4 }
\end{aligned}
$$

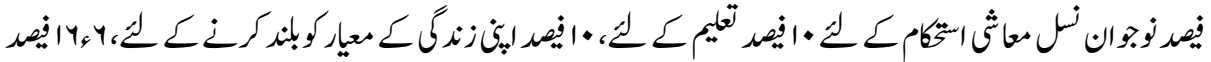

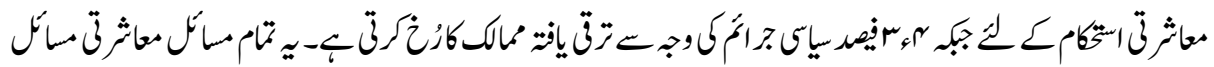

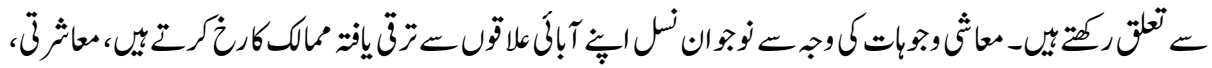




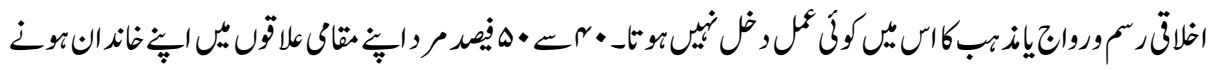

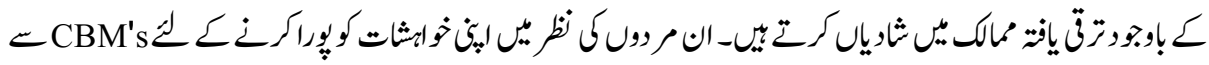

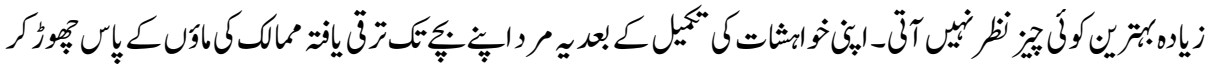

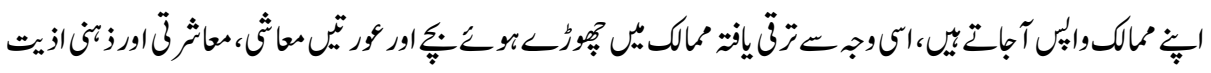

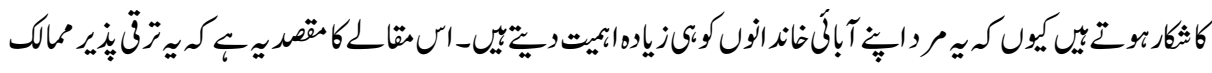

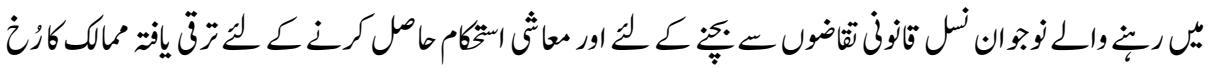

$$
\begin{aligned}
& \text { كرتب ب. }
\end{aligned}
$$

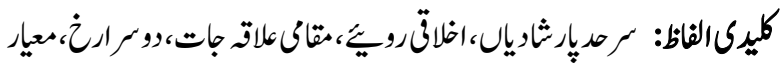

\section{Introduction}

Cross Border Marriages (CBM'S) have become an important and an under studies issue in immigration developed countries, particularly from third biosphere states to first biosphere states. It is also a new topic for the researchers of economics and social scientists. Gradually CBM'S have become an important socio-economic phenomenon. In this paper researchers aimed to understand CBM'S from the perspective of the persons concerned by investigating their performance, strategies, and depiction of relatives, gender, traditions and the consequential divergence. According to Morokvasic (1983) women do CBM'S for economic stability, financial and future security while according to Phizacklea (1983), Pessar \& Mahler (2001), Danneker (2005), Palriwala (2005), Suzuki (2005), Thai (2008) said that women do CBM'S to look after their families and to overcome the scarcity and personal dissatisfaction. According to Yang \& Lu (2010) CBM'S are the product of the lower - class - men who suffer the disadvantaged position in the domestic marriage market, thus, utilizing globalizing capital to get better their marriageability.

The main phenomena of CBM'S for Pakistanis is to get economic sustainability and luxuries stability, get rid of poverty and to provide money to their innate families to improve their standard of living. Before 1970's CBM'S was not famous in Pakistan as Lu \& Yang (2010) pointed out that in Asia due to CBM'S late marriages are occurring and its result are biased sex ratio, sexual harassment, infertility and divorce rate.

\section{Literature Review}

According to L. Melody (2007) the meaning of CBM'S is terrestrial, national, ethnic, class, gender and racial borders created in the hosting societies. These borders are mostly 
mediated by the states as well as other social actors in regulating to discriminate the "WE" and the "OTHERS". Rendering to Tseng (2010) determined that through CBM'S females are moved from third world countries to first world countries for economic stability. According to Wang \& Chang (2002) very little research has been done on CBM'S. Hugo (2005a) implies that the history of CBM'S started from the arrangement of European's in Australia. At that time the sex ratio between genders was unequal. Now this phenomenon is increasing day by day. According to Wang \& Chang (2002), Jones \& Shen (2007) and Yang \& Chia (2010) CBM'S are quite common between South-East Asia and East Asia since last ten years. While according to Buijs (1996), Asis (2001), Nguyen \& Hugo (2005), Belanger \& Pendakis (2009) and Tseng (2010) CBM'S are fairly common from under-develop nations to developed nations. After the event of 9/11 CBM'S grew to alarming point, especially significant numbers of CBM'S from Pakistan to other developed countries are quite alarming because the main focus of it is to get financial stability, neither cross culture nor kinship obligations. According to Stoler (2003), Belanger \& Khuat (2002), Constable (2003), Phan (2005), Belanger (2007), Ghosh (2009), Stoler (1991), Belanger \& Khuat (2002), Constable(2003), Phan (2005), Belanger(2007) and Ghosh (2009) CBM'S is also making the disparity in different economic factors like per capita income and economic growth. Socially it makes dissimilar new concepts, attitudes, cultures, norms, gender sex ratio, marriageable age between the crowded and abode country society. It means that CBM'S is becoming a factor for changing the world's social structure. According to Zhao (2003) CBM'S also creates world labor market. Shih (1998) and Li (2001) noticed that CBM'S are the burning questions in the world because due to it globally constructed values have often changed.

According to Sung (1990) and Hugo (2005a) due to CBM'S many women and their families have suffered. Palriwala \& Uberio (2005), De Haas (2007), Wang \& Belanger (2008) and Lutz \& Erel (2012) understood that this geographical mobility changes the economic and social myths and norms. According to Hugo (2005c) CBM'S provide the great opportunity to enhance the economic remuneration. According to Rosenzweig \& Stark (1989), Wang \& Change (2002), Hugo \& Nguyen (2007) and Belanger \& Linh' (2011) through CMB'S third world countries women get economic stability and wealth. Do et al (2003), Oxford (2005) and Farrer (2008) pointed out that through CBM'S women earn social and economic status. While Glodava (1994) and Cunneen \& Stubbs (1997) noticed that CBM'S may increase social and economic disadvantages as well. Piper (1997) and Tseng (2010) imply that this is the only legal way to improve communal status and obtains nationality or long - term residence in a developed country. According to Constable (2005) third world countries gender have the desire to leave their norms, myths, customs, traditional values, patriarchal terrorism through CBM'S. According to Yang \& Lu (2010) Asian women get CBM'S for equal rights between men and women. Schein (2010) implies that people use CBM'S to provide better socio-economic 
circumstances at homes as well as communities. East Asian countries that see CBM'S as a solution to low fertility rate and shortage of wives and reproductive labor. Toyota (2008) argues that people get CBM'S just only to maintain social, political and economic stability. The demand of Asian unmarried and young men is too much in the first world countries regarding CBM'S. Another reason of CBM'S is unemployment within the country because a man is usually anticipated to have attained some measures of economic steadiness before he marries (G. Shahnaz, 2010). According to Constable (2005) CBM'B in Asia places the changing social positing before and after CBM'S at the center in the migratory process. She proposed the concept "Paradoxical hyper gamy" that migrants may find that their economic position and opportunities have improved after migration to rich country while, their social positions in the native society and in the husbands kin groups are lower than the ones to migration in their host society. Young Pakistani gender doing CBM'S as a shortcut to exit in developed countries. Frustrated and instable economic, political and limited opportunities provoke the youth for this action.

\section{Methodology}

Qualitative and quantitative methods were employed for this study.30 respondent taken under consideration in this research with review of global literature. Interviews were conducted for data collection at the respondent's home. Researcher collected data from December 2011 to 2015 residing in Karachi and Islamabad. Purposive sampling method was used for data collection. Researcher chooses this area of research because large number of marriage migrant had left Pakistan over the past three decade. According to Guthrie (2010) almost social scientists follow the scientific research method and apply quantitative methodology. The purpose of the quantitative interview was to know about the economic position of the respondents and their families before CBM'S. Interviews are the fundamental starting place of many facts because interviews are a productive way to gather remarkable information from the respondents. Open- ended and close - ended format of questionnaire is used. In this way it is easy to acquire quantitative facts from the assorted choice options. Through this method researcher gets an obvious picture about the CBM'S and this gave respondents the opportunity to state their opinions without being restricted by limited multiple choice options and explain their answers properly and detailed.

\section{Key Findings}

The study was conducted to find out the main reason, why Pakistani youth as well as adults want to go to developed countries. Findings show that the main reason for leaving their own country is, improving economic stability in their lives, poverty and unemployment. Secondly the reason is to improve education, among many other reasons improving family status and family honor in the community and society. It is supposed 
that men satisfy their sexual desires and successfully prevent the issue of being alone. In Pakistan Joint family system is quite common as well as nuclear families are also established, in both systems native families support their bread earners to get better job opportunity by all means because they expect that they will give economic stability in future establishment .Due to this reason their family especially wives suffer, whereas, other family members have usual lives, even their husbands have advantage of polygamy with the foreign women and gets a legal cover to their stay in a foreign country.

$60 \%$ respondents were leaving abroad for economic stability. $10 \%$ go for better education. $10 \%$ go for improving standard of living, $16.6 \%$ go for economic and education while $3.4 \%$ go for political asylum or escape from cases being registered criminal issue and cases (Table 1). According to the International Migration Organization, in 2009, the number of international migrants under the family meeting system specially CBM'S accounted for around 35\% of the total number of international migrants around the world. It means CBM'S provide a great opportunity to enhance the economic remuneration and geographical mobility. It changes the economics rather social myths and norms because the people have the desired to leave their norms, myths, customs, traditional values, patriarchal dominancy and terrorism etc.

46\% CBM'S happen just for economic stability. 8\% CBM'S for sexual satisfaction. 3.3\% CBM'S for second family formation \& residence while $23.3 \%$ to avoid loneliness in foreign country (Table 2). Results clearly show that economical need is a main issue of CBM'S. Asian youth clearly understand that for International migrant CBM'S is an actual protected mode of migrating overseas. It shows that socially it makes dissimilar new concepts, attitudes, cultures, norms, gender sex ratio, marriageable age between the crowd and abode country society. It means that CBM'S is becoming a factor for changing the world social structure.

$53.3 \%$ males get financial stability, 16.7 get level of satisfaction, $20 \%$ were far from their loving native families while only $10 \%$ fulfilled all of their desires (Table 3). It means through CBM'S respondents fulfill their all anticipations, intentions and desired.

It is important that $93.33 \%$ people don't want to come back to their innate families because they suppose that if they come back then they will become economically unstable and also they become habitual of luxuries life which is not available at their inborn countries. Only 6.7\% want to come back to their country (Table 4).

Education qualification of the men was varying. Study shows that $13.3 \%$ were matriculate. $20 \%$ were Intermediate and $6.7 \%$ were graduate, while $10 \%$ were post graduate, 26.7 had technical education, whereas $23.3 \%$ were having any professional degree (Table 5). Results shows that all the people who want to go to abroad were educated. 
Due to CBM'S $53.3 \%$ respondents native wife suffered, $40 \%$ foreigner wife suffered while only $6.7 \%$ man suffered by themselves (Table 6).According to Constable (2005) CBM'B in Asia places the shifting social situation afore and later CBM'S at the midpoint of the migratory development. Women in Asia usually are strictly socially, religiously, spiritually and economically prohibited to entertain her without their husbands so they are mentally and physically disturb. She also propose the concept of "PARADOXICAL HYPER GAMY" that asylum seeker may find that their economic position and opportunities have upgraded after CBM'B to wealthier state while their social places in the receiving society and in the husbands kin groups are lower than the ones to migration in their sending society.

Gender was not considered by the researcher during research, randomly selected $80 \%$ respondents were male. The researcher was most interested in the person irrespective of gender, who could explain either one or more aspects of CBM'S. All the male and female respondents had his/her own mentality regarding their myths, norms, customs, religion, ethnicity, socially constructed values and surrounded environment but one thing was same that all the respondents needed better lives. Due to this mentality they used CBM'S.

Before CBM'S the families of respondents were from poor income families. They all belonged to low class families with large family size. They earn money by all means but $25 \%$ respondent never left their education, even they did odd jobs to continue their education. $25 \%$ earned money by the working in the different political parties. Educated respondents earned money by home tuitions in the upper class families.

According to a British Higher Education Statistics Agency Report, Pakistan accounts for 54 per cent of UK's (non-EU) international students. In 2009-2012 there were over 9, 815 Pakistani students enrolled in higher education institutes. Furthermore, popular countries such as Canada, North America, several North European countries, including Sweden and Finland are attracting thousands of Pakistani students to their universities. More than 8,458 Pakistani students studied in Australia in 2009-2010, increase of $11.4 \%$ over 20082009. Once these men secure their enduring visas, to attain their goal they take the alternate ways. Left they are troubled and mentally distressed women who have no alternates but to either wait due to family commitments or face social challenges if they leave their families behind. Pakistani families need to be cautious about assessing prospective spouses for their dear ones by thorough background check, assess their emotional involvement towards their spouse to-be, getting personal information and assessing their trust worthiness. A time where Pakistan already faces political, economic and social challenges nationally and in the internationally, the country cannot afford individuals to damage its image any further. 
Through CBM'S men is not only pampering the lives of acquitted women in Pakistan for their self-vested curiosity abroad but sendoff a communal disgrace for both these women residing overseas and in Pakistan.

\section{Recommendations}

- The state should be able to create employment in easy way in government, public or private sector because a man is usually anticipated to have attained some measures of economic steadiness before he married

- Try to change the social norms, customs and myths regarding marriages. There is a need to raise and facilitate the CBM'S couples in first world countries as well as third world countries.

- Workshops, open seminars should be held for awareness rising in common public.

\section{Conclusions}

According to Constable (2005) CBM'S do not occur in random geographic topologies but are rather shaped and limited by exciting and gives rise to cultural, social, historical, political and economic factors. The researcher also noticed that by global marriage chains, referring to a phenomenon in which inter- ethnic- marriages a cross border are often triggered by a previous wave of within group marriage migration. The people who do CBM'S suppose that the host society provides financial stability. According to F. Michele \& L. Lenore (2008) CBM'S between Pakistani men and Japanese women occurred only for job opportunities, economic motivation and culture practice. It was also noticed that Japanese women want to establish their home at UAE rather Pakistan because of the modern lifestyle and less control from their husband's family and enjoy the social support of some kin members as well. CBM'S create many answerable questions for the social scientists like:

- How to delineate this type of family component?

- Is CBM'S providing the level of gratification to the 3rd world republics folks?

- How gender kindred are being prearranged in CBM's?

- How do family members interconnect and interact across the border?

The growing number of CBM'S in the European Union creates kin groups of different national origins to a new social unit and creates affiliations and obligations across different states. L.Jutta (2010) describe that partners living in "mixed marriages" have to develop new strategies to cope with the dispersed family network and to organize interaction with family members within and beyond the borders. CBM'S are considered that it is the ticket for immigration of developed countries. The research found out that through CBM'S third world countries gender fulfill their financial needs and enjoying luxuries life but usually they lose their moral attitudes and native family love. It was also 
found that the major reason is economic perspective rather other factors. education is also a priority given by the respondents.

\section{References}

Asis, M. MB. (2001). (eds.) The Return Migration of Filipino Women Migrants: Home, but not for Good. Willie C and Passl B. Female Labor Migration in South-East Asia. Bangkok: Asian Research Center for Migration, pp.23-93.

Belanger, D. \& K.L. Pendakis. (2009). (eds.) Daughters, Work, and Families in Globalizing Vietnam in: M. Barbieri and D. Belanger, Reconfiguring Families in Contemporary Vietnam. Stanford: Stanford University Press, pp.265-297.

Belanger, D. \& T.H. Khuat. (2002). Too Late to Marry: Failure, Fate or Fortune? Female Singlehood in Rural North Vietnam. Gender, Household, State: DoiMoi in Viet Nam. J. Werner and D. Belanger. Cornell, Southeast Asia Program, Cornell University, pp.89-110.

Belanger, D. (2007). The House and the Classroom: Vietnamese Immigrant Spouses in South Korea and Taiwan. Population and Society, vol.3:1, pp.1-38.

Belanger.D. \& T.G. Linh. (2011). The Impact of Transnational Migration on Gender and Marriage in Sending Communities of Vietnam, Current Sociology, vol.59:1, pp.59-77.

Buijs, G. (1996). (ed.) Migrant Women: Crossing Boundaries, Changing Identities. Oxford: Berg.

Constable, N. (2003). Romance on a Global Stage: Pen Pals, Virtual Ethnography and "Mail Order" Marriages. Berkeley, CA: University of California Press.

Constable, N. (2005). Introduction: Cross-border Marriages, Gendered Mobility, and Global Hyper Gamy, Cross-border Marriages. Gender and Mobility in Transnational Asia. Philadelphia: University of Pennsylvania Press, pp.1-16.

Cunneen, C. \& J. Stubbs. (1997). Gender, Race, and International Relations: Violence against Filipino Women in Australia. Sydney: Institute of Criminology, University of Sydney Faculty of Law. 
Danneker, P. (2005). Transnational Migration and the Transformation of Gender Relations: The Case of Bangladeshi Labor Migrants. Current Sociology, vol.53:4, pp.655- 674 .

De Haas, H. (2007). The Impact of International Migration on Social and Economic Development in Moroccan Sending Regions: A Review of the Empirical Literature. Working Papers No. 3. International Migration Institute, University of Oxford.

Do, T.N.T., Glind, H. Kelly, P., Kamphuis, G., Heeswijk, M., McArthur, D., Phan, N.L., Tong, T.M.S., Tran, A.M. \& Tran, T.N.T. (2003). Marriages of Convenience: Context, Processes and Results of Cross-Border Marriages between Vietnamese Young Women and Taiwanese Men, Mobility Research and Support Center, Hanoi.

F.Michele \& L.lenore (2008). Love, Sex and the Spaces in-between: Kepri Wives and their Cross-Border Husbands, Taylor Frinces on-line, pp.55-72.

Farrer, J. (2008). From Passports to Joint Ventures: Intermarriages between Chinese Nationals and Western Expatriates Residing in Shanghai. Asian Studies Review, vol.32:1, pp.7-29.

G. Shahnaz. (2010). Family Planning: An Important Issue in the Light of Islamic Teaching. Pakistan Journal of Gender Studies, Centre of Excellence for Women Studies, University of Karachi, vol.4, p.97.

Ghosh, B.N. \& H. M. Guven. (2006 - 2009). Promoting the Value of Girl Child: Preventing Child Marriage in Malda District of West Bengal, Kolkata: UNICEF.

Glodava, M. (1994). Mail-Order Brides: Women for Sale. Fort Collins, Colorado: Alaken, Inc.

Guthrie. (2010). Basic Research Methods: An Entry to Social Science Research, London: Sage.

Hugo, (2005a). The New International Migration in Asia. Asian Population Studies, vol.1:1, pp.93-120.

Hugo, G. (2005c). United Nations. April 2006. Personal Communication. 
Hugo, G. \& Nguyen. THX. (2007). Marriage Migration between Vietnam and Taiwan: A View from Vietnam. Attane.I. and Christophe. Z. Eds. Watering the Neighbor's Garden: The Growing Demographic Female Deficit in Asia. Guilmoto, CICRED: Paris: pp.365-392.

Jones, G. \& H.H., Shen. (2007). International Marriage in East and Southeast Asia: Trends and Research Emphases. Citizenship Studies, vol.12:1, pp.9-25.

L. Jutta (2010). Cross-Border Marriages and the Formation of Transnational Families: A Case Study of Greek-German Couples in Athens WPTC-02-10.

Lutz, H. \& U. Erel (2012). Gender and Transnational's. Gender Institute. Feminist Review Issue.

Morokvasic, M. (1983). Women in Migration: Beyond the Reductionist Outlook in A. Phizacklea. Ed. One Way Ticket: Migration and Female Labor. London: Routledge \& Kegan Paul.

Nguyen, T, H. X. (2005). Marriage Migration between Vietnam and Taiwan: A View from Vietnam. Seminar on Female Deficit in Asia: Trends and Perspectives. Singapore. December.

Oxford, E. (2005). Cross-Border Hyper Gamy? Marriage Exchanges in a Transnational Hakka Community. 17-33. Cross-border Marriages. Gender and Mobility in Transitional Asia, Constable. (2005). Philadelphia: University of Pennsylvania Press.

Palriala, R. \& P., Uberio. (2005). Marriage and Migration in Asia: Gender Issues.Indian Journal of Gender Studies, vol.12:3, pp.5-29.

Pessar, P. \& S. J. Mahler. (2001). Gendered Geographies of Power: Analyzing Gender Across Transnational Spaces. Identities: Global Studies in Culture and Power 7: $1-16,441-459$.

Phan, A. \& others. (2005). Phenomenon of Vietnamese Women Getting Married to Taiwanese men, Ho Chi Minh City.

Phizacklea, A. (1983). One Way Ticket: Migration and Female labor. Eds. Routledge and Kegan Paul: London and Boston. 
Piper, N. (1997). International Marriage in Japan: "race" and "gender" Perspectives. Gender, Place and Culture, vol.4:3, pp.321-338.

Rosenzweig, R.M. \& Stark. O. (1989). Consumption Smoothing, Migration, and Marriage: Evidence from Rural India. Journal of Political Economy, vol.94:4, pp.905-926.

Schein L. \& B. Vang. (2010). Gran Torino's Hmong Lead Bee Vang on Film, Race and Masculinity: Conversations with Louisa Schein, Spring 2010. Hmong Studies Journal, 11: 1-11. http://hmongstudies.org/ScheinVangHSJ11.pdf.

Shih, S.M. (1998). Gender and a New Geopolitics of Desire: The Seduction of Mainland Women in Taiwan and Hong Kong. 208. Nicole. Constable. 2005. Cross- Border Marriages: Gender and Mobility in Transnational Asia. University of Pennsylvania Press.

Stoler, A. L. (1991). (ed.) Carnal Knowledge and Imperial Power: Gender, Race, and Morality in Colonial Asia. 51-101. Gender at the Crossroads of Knowledge: Feminist Anthropology in the Postmodern Era. Micaela di Leonardo. Berkeley: University of California Press.

Sung, B. (1990). Chinese American Intermarriage, Center for Migration Studies, New York. TECO (Taipei Economic and Cultural Office.)Statistics on TaiwaneseVietnamese Marriages.

Suzuki, Nobue (2005). Tripartite Desires: Filipina-Japanese Marriages and Fantasies of Transnational Traversal. pp. 124-44 in Cross-Border Marriages: Gender and Mobility in Transnational Asia, edited by N. Constable. Philadelphia, PA: University of Pennsylvania Press.

Thai, H.C. (2008). For Better or for Worse: Vietnamese International Marriages in the New Global Economy. New Brunswick. NJ: Rutgers University Press.

Toyota, Mika (2008). Editorial introduction: International Marriage, Rights and the State in East and Southeast Asia. Citizenship Studies, vol.12, pp.1-7.

Tseng, Y.F. (2010). Marriage Migration to East Asia: Current Issues and Propositions in Making Comparisons. 31-48. Yang and Lu.eds. Asian Cross-border Marriage Migration- Demographic Patterns and Social Issues. 
Wang, H. \& Belanger. D. (2008). Taiwanizing Female Immigrant Spouses and Materializing Differential Citizenship. Citizenship Studies, vol.12:1, pp.91-106.

Wang, H.Z., Chang, S. M., (2002). The Commodification of International Marriages: Cross-Border Marriage Business in Taiwan and Vietnam. International Migration, vol.40:6, pp.93-116.

Yang, L.Y. \& Chang. (2010). (ed.) Asian Cross-Border Marriage Migration: Demographic Patterns and Social Issues. Amsterdam University Press: Amsterdam.

Yang, W. S. \& L. M. Chia-wen. (2010). (eds.) Asian Cross-Border Marriage. Demographic Patterns and Social Issues. Amsterdam 2919. Amsterdam University Press.

Zhao, G.M. (2003). Trafficking of Women for Marriage in China: Policy and Practice. Criminal Justice, vol.3:1, pp.83-102. 


\section{Annex: Tables of the Study Findings}

Table 1

Distribution according to reason for leaving home country

\begin{tabular}{|l|c|c|}
\hline Reason For Leaving Home Country & Frequency & Percentage \\
\hline Economics Stability & 18 & 60 \\
\hline Education & 3 & 10 \\
\hline Improve Standard of Living & 3 & 10 \\
\hline Economics \& Education & 5 & 16.6 \\
\hline Political or Criminal Issue & 1 & 3.4 \\
\hline Total & $\mathbf{3 0}$ & $\mathbf{1 0 0}$ \\
\hline
\end{tabular}

Table 2

Distribution according to reason for CBM'S

\begin{tabular}{|l|c|c|}
\hline Reason for CBM'S & Frequency & Percentage \\
\hline Economics Stability & 14 & 46.7 \\
\hline Sexuality & 8 & 26.7 \\
\hline 2nd Family Formation \& Residence & 1 & 3.3 \\
\hline Loneliness & 7 & 23.3 \\
\hline Total & $\mathbf{3 0}$ & $\mathbf{1 0 0}$ \\
\hline
\end{tabular}

Table 3

Distribution according to through CBM'S respondents gets

\begin{tabular}{|l|c|c|}
\hline $\begin{array}{l}\text { Reason for Through CBM'S } \\
\text { Respondents Gets }\end{array}$ & Frequency & Percentage \\
\hline Financial Stability & 16 & 53.3 \\
\hline Level of Satisfaction & 5 & 16.7 \\
\hline Far From Their Loving Native Families & 6 & 20 \\
\hline Fulfill Their All Desires & 3 & 10 \\
\hline Total & $\mathbf{3 0}$ & $\mathbf{1 0 0}$ \\
\hline
\end{tabular}

Table 4

Distribution according to people wants to come back to Pakistan

\begin{tabular}{|l|c|c|}
\hline Reason For Back To Pakistan & Frequency & Percentage \\
\hline Yes & 28 & 93.33 \\
\hline No & 2 & 6.7 \\
\hline Total & $\mathbf{3 0}$ & $\mathbf{1 0 0}$ \\
\hline
\end{tabular}


A Socio-Economic Perspective

Table 5

Distribution according to education

\begin{tabular}{|l|c|c|}
\hline Education Level & Frequency & Percentage \\
\hline Matric & 4 & 13.3 \\
\hline Inter & 6 & 20 \\
\hline Graduate & 2 & 6.7 \\
\hline Post Graduate & 3 & 10 \\
\hline Technical & 8 & 26.7 \\
\hline Professional & 7 & 23.3 \\
\hline Total & $\mathbf{3 0}$ & $\mathbf{1 0 0}$ \\
\hline
\end{tabular}

Table 6

Distribution according due to CBM'S which wife suffers more, native or foreigner

\begin{tabular}{|l|c|c|}
\hline Survival by CBM'S & Frequency & Percentage \\
\hline Native Wife & 16 & 53.3 \\
\hline Foreigner Wife & 12 & 40 \\
\hline Himself & 2 & 6.7 \\
\hline Total & $\mathbf{3 0}$ & $\mathbf{1 0 0}$ \\
\hline
\end{tabular}

Shagufta Jahangir is Ph.D Scholar in the Centre of Excellence for Women's Studies, University of Karachi.

Dr. Asma Manzoor is an Assistant Professor in the Centre of Excellence for Women's Studies, University of Karachi. 